\title{
Seroprevalence of hepatitis B and C virus markers among blood donors in Rio de Janeiro, Brazil, 1998-2005
}

\author{
Ana FB Andrade, Michelle Oliveira-Silva*, Suely GC Silva**, lara JF Motta**, \\ Cibele R Bonvicino****/+
}

\begin{abstract}
Programa de Pós-graduação em Biologia Celular e Molecular ***Departamento de Medicina Tropical, Instituto Oswaldo Cruz-Fiocruz, Av. Brasil 4365, 21040-900 Rio de Janeiro, RJ, Brasil *Divisão de Genética **Laboratório de Sorologia, Instituto Nacional de Câncer, Rio de Janeiro, RJ, Brasil
\end{abstract}

\begin{abstract}
The prevalence of infection by hepatitis $B(H B V)$ and $C(H C V)$ viruses varies among geographical regions. In order to determine the prevalence of $H B V$ and $H C V$ infection in voluntary blood donors we evaluated the prevalence of HBsAg, anti-HBc, and anti-HCV markers of 128,497 blood donor samples collected from 1998 to 2005 in the state of Rio de Janeiro. These markers were analyzed by immunoenzymatic tests, as determined by the Ministry of Health. Data were obtained from the Sorology Laboratory of the Hemoterapy Service of the Instituto Nacional de Câncer, Rio de Janeiro. Overall prevalence estimates were: $0.27 \%$ for $\mathrm{HBs} A g, 3.68 \%$ for anti-HBc, and $0.90 \%$ for anti-HCV. There was a significant decrease in the overall prevalence of HBsAg (from 0.36 to $0.14 \%$ ) and anti-HBc (from 6.12 to 2.05\%) in the period encompassed between 1998-2005. Similarly, there was a decline in anti-HCV prevalence rates in Brazilian blood donors, from 1.04\% in 1998 to $0.79 \%$ in 2004, with an increase of HCV prevalence to $1.09 \%$ in 2005. These prevalence estimates were higher than those found in other countries, indicating high rates of infection by $H B V$ and $H C V$ and a persistent risk of $H B V$ and $H C V$ transmission by transfusion.
\end{abstract}

Key words: hepatitis B virus - hepatitis C virus - blood donors - seroprevalence -Brazil

Infection by hepatitis $\mathrm{B}$ virus (HBV) and hepatitis $\mathrm{C}$ virus $(\mathrm{HCV})$ is a worldwide public health problem, representing a significant cause of morbidity and mortality, especially in developing countries. It is estimated that 350 million people worldwide are chronic HBV carriers, representing approximately $7 \%$ of the total population (Kao et al. 2002) while HCV infection is found in approximately $3 \%$ of the world population, accounting for 160 million people (Frider 2000, Zou et al. 2000). Their transmission occurs, mainly, through direct contact with blood, intravenous injections, transfusion of blood and/or hemocomponents, and sexual relations, this last, mainly in HBV carries (Wright et al. 1994). In HCV carries the sexual transmission is controversial (Tahan et al. 2005). Chronic HBV infection is prevalent in Southeast Asia, China, and Africa, where over $10 \%$ of the population may be infected (Purow \& Jacobson 2003). In these countries, vertical transmission is important (Custer et al. 2004). In Western Europe and North America, the hepatitis B affects less than $1 \%$ of the population, although more than 1 million people in the United States are chronically infected (Purow \& Jacobson 2003). In Brazil, prevalence of $\mathrm{HBV}$ is variable, increasing from South to North. Previous studies detected low infection rate in Southern Brazil, middle rate in Northeast and Southeast, and high prevalence in the Amazon

Financial support: Fundação Ary Frauzino, CNPq

${ }^{+}$Corresponding author: cibelerb@inca.gov.br

Received 28 April 2006

Accepted 12 July 2006 region, state of Espírito Santo, and in west of the state of Santa Catarina (Ministério da Saúde - MS 2004).

Over many years, hepatitis was the main cause of transfusion-associated chronic disease, liver cirrhosis, hepatocellular carcinoma, and death (Chattopadhyay et al. 2005). Since 1993, the screening of blood donors for HBV and $\mathrm{HCV}$ infection became obligatory in Brazil as part of the HIV control program, leading to a tighter control of blood samples used in transfusion (Gonçales Junior 1998). In Brazil, the official immunization schedule includes the HBV vaccine, only for newborns, children and young adults less than 19 years, although the vaccine is available in the government health program (Sistema Único de Saúde - SUS, MS) for populations at risk of HBV infection. In Brazil, however, few studies have been carried out on the prevalence of $\mathrm{HBV}$ and $\mathrm{HCV}$ markers in blood donors. These showed a wide variation of $\mathrm{HBV}$ and $\mathrm{HCV}$ markers prevalence in Brazilian territory; in the Amazon region, a recent prevalence estimate accounted for 3.3\% of HBsAg, $49.9 \%$ of anti-HBc (Braga et al. 2005), and 5.9\% of anti-HCV (Da Fonseca \& Brasil 2004). Arraes et al. (2003) found an anti-HBc prevalence of $12 \%$ in Recife, while Almeida Neto et al. (2001) found 16\% in São Paulo. Rosini et al. (2003) collected data from the state of Santa Catarina and found a prevalence of $0.64 \%$ to $\mathrm{HBsAg}, 5.35 \%$ of anti-HBc and $0.34 \%$ of anti-HCV.

Our objective was to determine the prevalence of HBV and $\mathrm{HCV}$ infection in voluntary blood donors using hepatitis B surface antigen (HBsAg), hepatitis B core antigen (anti-HBC), and hepatitis C antibody (anti-HCV) serological assays. This report presents the results of a retrospective study of screening blood donors in the state of Rio de Janeiro, Brazil from 1998 to 2005. 


\section{MATERIALS AND METHODS}

We analyzed data collected from the Serviço de Hemoterapia do Laboratório de Sorologia (Sorology Laboratory in Hemoterapy Service) of Instituto Nacional de Câncer in Rio de Janeiro from 1998 to 2005. HBV markers were analyzed with Microparticle Enzyme Immunoassay (MEIA-Abbott AxSym System Laboratories, Deerfield, IL, US). The 3.0 version of the same system was used for analyzing anti-HCV (HCr43, c200, c100-3, and NS5). Identification of $\mathrm{HBV}$ and $\mathrm{HCV}$ infection markers was carried out according to Ministry of Health directives 1376 of 1993. $\chi^{2}$ analyses were carried out for verifying significant alterations in the mean prevalence of these markers.

\section{RESULTS}

We analyzed data from 128,497 blood samples collected from 1998 to 2005. In this period, approximately 57,823 were repetition donors, which correspond to $45 \%$ of the number of blood donors. Prevalence of HBsAg, anti-HBc, and anti-HCV in blood donors are shown in the Table. The overall HBsAg prevalence was $0.27 \%$ (347/ $128,497)$, anti-HBc prevalence was $3.68 \%(4723 / 128,497)$, and anti-HCV prevalence was $0.90 \%(1153 / 128,497)$. There was a steady decrease in the overall prevalence of HBsAg and anti-HBc-positive individuals from 1998 to 2005. HBsAg prevalence estimates dropped significantly from $0.36 \%$ in 1998 to $0.14 \%$ in $2005(\mathrm{p}<0.001)$, and at the same time, anti-HBc estimates also dropped significantly from $6.12 \%$ in 1998 to $2.05 \%$ in 2005 ( $p<0.001$ ). Similarly, there was a decline in anti-HCV prevalence among Brazilian blood donors from $1.04 \%$ in 1998 to $0.79 \%$ in 2004 (p < 0.001 ), although the HCV prevalence increased not significantly to $1.09 \%$ in 2005 (Figure).

\section{TABLE}

Decreasing rates of hepatitis B virus markers and maintenance of anti-HCV among blood donors in Rio de Janeiro, period 1998-2005

\begin{tabular}{ccccc}
\hline & \multicolumn{3}{c}{ Markers } \\
\cline { 3 - 5 } Year & & HBsAg & anti-HBc & anti-HCV \\
\hline \multirow{2}{*}{1998} & $\mathrm{~N}$ & $48 / 13,363$ & $818 / 13,363$ & $139 / 13,363$ \\
& $\%$ & 0.36 & 6.12 & 1.04 \\
1999 & $\mathrm{~N}$ & $54 / 17,103$ & $807 / 17,103$ & $178 / 17,103$ \\
& $\%$ & 0.32 & 4.72 & 1.04 \\
2000 & $\mathrm{~N}$ & $72 / 18,214$ & $712 / 18,214$ & $172 / 18,214$ \\
& $\%$ & 0.4 & 3.91 & 0.94 \\
2001 & $\mathrm{~N}$ & $56 / 19,256$ & $678 / 19,256$ & $169 / 19,256$ \\
& $\%$ & 0.29 & 3.52 & 0.88 \\
2002 & $\mathrm{~N}$ & $38 / 17,374$ & $572 / 17,374$ & $135 / 17,374$ \\
& $\%$ & 0.22 & 3.29 & 0.78 \\
2003 & $\mathrm{~N}$ & $41 / 15,821$ & $480 / 15,821$ & $114 / 15,821$ \\
& $\%$ & 0.26 & 3.03 & 0.72 \\
2004 & $\mathrm{~N}$ & $24 / 17,059$ & $445 / 17,059$ & $134 / 17,059$ \\
& $\%$ & 0.14 & 2.61 & 0.79 \\
2005 & $\mathrm{~N}$ & $14 / 10,307$ & $211 / 10,307$ & $112 / 10,307$ \\
& $\%$ & 0.14 & 2.05 & 1.09 \\
\hline
\end{tabular}

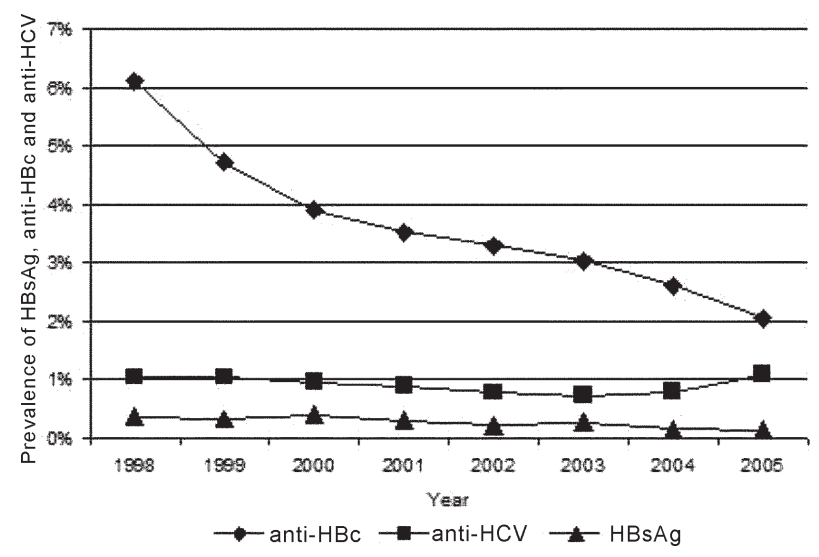

Graphic showing the prevalence of $\mathrm{HBsAg}$, anti-HBc, and antiHCV positive blood donors in Rio de Janeiro in the period encompassed between 1998-2005.

\section{DISCUSSION}

We verified that the prevalence of HBsAg and anti$\mathrm{HBc}$ markers in Rio de Janeiro declined, although the mean prevalence of anti-HCV did not change significantly from 1998 to 2005 . In this study, the overall, $0.27 \% \mathrm{HBsAg}$ prevalence in volunteer blood donors from Rio de Janeiro, in the period encompassed between 1998-2005, was lower than in Lábrea, state of Amazonas (3.3\% in 2000) (Braga et al. 2005) and state of Santa Catarina (0.7\% in 1994-1995) (Treitinger et al. 2000), and in 1999-2001 (0.98, 0.84, and $0.64 \%$ respectively) (Rosini et al. 2003). However, a comparison with developed countries, like Germany $(0.16 \%$ in 1997-2002) (Offergeld et al. 2005), United States $(0.07 \%$ in 2002) (Zou et al. 2004), Italy (0.003\% in 1994-1997) (Tosti et al. 2002), and Canada (0.012\% in 2000) (Chiavetta et al. 2003) showed that HBsAg prevalence estimates in Rio de Janeiro blood donors were higher.

The overall prevalence for anti-core antibody $(\mathrm{HBc})$ in the Rio de Janeiro sample (3.68\%) was lower than in the state of Santa Catarina in 1999-2000-2001 (8.83, 7.09, and $5.35 \%$ respectively (Rosini et al. 2003). The anti-HBc prevalence in 1998 was $6.12 \%$ in our sample, contrary to $12 \%$ in Recife in 1997 (Arraes et al. 2003), showing that despite the high anti-HBc prevalence in Brazil, HBV infection is not highly endemic in Rio de Janeiro. Anti-HBc prevalence in Rio de Janeiro in 1998 (6.12\%) was similar to HBV prevalence in Colombia (6.8\%), Panama (6.7\%), but higher than in other Latin American countries for the year 1997: Chile (1.5\%), Costa Rica (3.8\%), Ecuador (3.9\%), El Salvador (3.8\%), Honduras (3.5\%), Nicaragua (3.1\%), Paraguay (5.6\%), and Uruguay (4.1\%) (Schmunis et al. 2001). The anti-HBc prevalence of Rio de Janeiro was also higher than in Italy (0.03\% in 1994-1997) (Tosti et al. 2002).

The overall prevalence for anti-HCV marker in blood donors in Rio de Janeiro, in 1988 to 2005, was $0.9 \%$. In Brazil, prevalence of anti-HCV marker has been found to be variable in different regions, ranging from $5.9 \%$ in the Amazon (Da Fonseca \& Brasil 2004) to 0.31\% in Santa Catarina (Rosini et al. 2003). The anti-HCV prevalence found in 1998 (1.04\%) was similar to the ones found in El 
Salvador (1.3\%) and Honduras (1.9\%) in the years 1994/ 1997, but much lower than in Chile (6.8\%), Venezuela (6.6\%), Costa Rica (4.6\%), Nicaragua (4.1\%), Panama (5\%), Paraguay (4.3\%), Peru (3.1\%), Uruguay (4.9\%), and Colombia (8.5\%) (Schmunis et al. 2001). Although the HCV prevalence is not high as in others Americans countries it is increasing since 2004. This data should be an alert to government focus actions in $\mathrm{HCV}$ prevention in view of the fact that vaccine is not available.

As the $\mathrm{HBsAg}$ and anti-HBc prevalence, the anti-HCV prevalence found in Brazil was higher than in developed countries like United States (0.25\% in 2002) (Dodd et al. 2002), Germany (0.1\% in 1997/2002) (Offergeld et al. 2005), Canada $(0.017 \%$ in 2000$)$ (Chiavetta et al. 2003), and Italy (0.002\% in 1994/1997) (Tosti et al. 2002).

Three factors may contribute to a large reduction of the main frequency of blood transfusion-associated hepatitis: systematic interviews with screening questionnaires and exclusion of donors reporting defined risk factors, introduction of third generation tests like ELISA for testing HBsAg and HCV antigens (increasing detection sensitivity for these viruses and reducing the window of detection), and/or an overall decrease in infection levels of these pathogens in the general population. Vaccination program of children and fertile age women against hepatitis B plays also an important role in decreasing the occurrence of hepatitis. The introduction of novel technologies for detecting viral nucleic acid, like PCR (polymerase chain reaction) and NAT (nucleic acid test), might have contributed to the decrease in prevalence of HBV and $\mathrm{HCV}$ because they are more sensitive and specific, and makes the infection window period shorter (Dodd et al. 2002).

Although HBsAg and anti-HBc mean frequencies in Rio de Janeiro have decreased, when compared to other countries, HBV and HCV prevalence in Brazil is high. This study also demonstrated that HCV infection is a serious problem in the Brazilian southeast region, which requires further studies and greater attention on the part of federal government health authorities.

\section{ACKNOWLEDGEMENTS}

To Dr Héctor N Seuánez for reviewing the manuscript.

\section{REFERENCES}

Almeida Neto C, Strauss E, Sabino EC, Sucupira MCA, Chamone D 2001. Significance of isolated hepatitis B core antibody in blood donors from São Paulo. Rev Inst Med Trop São Paulo 43: 203-208.

Arraes LC, Ximenes R, Andrieu J-M, Lu W, Barreto S, Pereira LMMB, Castelo A 2003. The biological meaning of anti$\mathrm{HBc}$ positive results in blood donor: relation to HBV-DNA and to other serological markers. Rev Inst Med Trop São Paulo 45: 137-140.

Braga WSM, Silva EM, Souza RAB, Tosta CE 2005. Soroprevalência da infecção pelo vírus da hepatite B e pelo plasmódio em Lábrea, Amazonas: estimativa da ocorrência de prováveis coinfecções. Rev Soc Bras Med Trop 38: 218223.

Chattopadhyay S, Rao S, Das BC, Singh NP, Kar P 2005. Prevalence of transfusion-transmitted virus infection in patients on maintenance hemodialysis from New Delhi, India. Hemodial Int 9: 362-366.

Chiavetta JA, Escobar M, Newman A, He Y, Driezen P, Deeks S, Hone DE, O'Brien SF, Sher G 2003. Incidence and estimated rates of residual risk for HIV, hepatitis C, hepatitis B and human T-cell lymphotropic viruses in blood donors in Canada, 1990-2000. CMAJ 169: 767-773.

Custer B, Sullivan SD, Hazlet TK, Iloeje U, Veenstra DL, Kowdley KV 2004. Global epidemiology of hepatitis B virus. J Clin Gastroenterol 38: S158-S168.

Da Fonseca JC, Brasil CM 2004. Hepatitis C virus infection in the Amazon Brazilian region. Rev Soc Bras Med Trop 37: 18.

Dodd RY, Notari EP $4^{\text {th }}$, Stramer SL 2002. Current prevalence and incidence of infectious disease markers and estimated window-period risk in the American Red Cross blood donor population. Transfusion 42: 975-979.

Frider B 2000. Epidemiologia de la hepatitis C. Acta Gastroenterol Latinoam 30: 142-144.

Gonçales Junior FL 1998. Prevenção das hepatites póstransfusionais. In DT Covas, MA Zago (eds), Atualização em Hemoterapia, Gráfica Canavaci, Ribeirão Preto, SP.

Kao JH, Chen PJ, Lai MY, Chen DS 2002. Occult hepatitis B virus infection and clinical outcomes of patients with chronic hepatitis C. J Clin Microbiol 40: 4068-4071.

Ministério da Saúde 2004. Doenças Infecciosas e Parasitárias: Guia de Bolso, 4th ed., Departamento de Vigilância Epidemiológica, Brasília, p. 172-176.

Offergeld R, Faensen D, Ritter S, Hamouda O 2005. Human immunodeficiency virus, hepatitis $\mathrm{C}$ and hepatitis B infections among blood donors in Germany 2000-2002: risk of virus transmission and the impact of nucleic acid amplification testing. Euro Surveill 10: 8-11.

Purow DB, Jacobson IM 2003. Slowing the progression of chronic hepatitis B: early antiviral therapy can help minimize complications. Postgrad Med 114: 65-76.

Rosini N, Mousse D, Spada C, Treitinger A 2003. Seroprevalence of HbsAg, Anti-HBc and Anti-HCV in Southern Brazil, 1999-2001. Braz J Infect Dis 7: 262-267.

Schmunis GA, Zicker F, Cruz JR, Cuchi P 2001. Safety of blood supply for infectious diseases in latin american countries, 1994-1997. Am J Trop Med Hyg 65: 924-930.

Tahan V, Karaca C, Yildirim B, Bozbas A, Ozaras R, Demir K, Avsar E, Mert A, Besisik F, Kaymakoglu S, Senturk H, Cakaloglu Y, Kalayci C, Okten A, Tozun N 2005. Sexual transmission of HCV between spouses. Am J Gastroenterol 100: 821-824.

Tosti ME, Solinas S, Prati D, Salvaneschi L, Manca M, Francesconi M, Ciuffreda M, Girelli G, Mele A 2002. An estimate of the current risk of transmitting blood-borne infections through blood transfusion in Italy. Br J Haematol 117 : 215-219.

Treitinger A, Spada C, Ferreira LA, Neto MS, Reis M, Verdi JC, de Miranda AF, de Oliveira OV, Van der Sander Silveira M, Abdalla DS 2000. Hepatitis B and hepatitis C prevalence among blood donors and HIV-1 infected patients in Florianopolis-Brazil. Braz J Infect Dis 4: 192-196.

Wright TL, Hollander H, Pu X, Held MJ 1994. Hepatitis C in 
HIV-infected patients with and without AIDS: prevalence and relationship to patient survival. Hepatology 20: 11521155.

Zou S, Notari IV EP, Stramer SL, Wahab F, Musavi F, Dodd RY 2004. Patterns of age- and sex-specific prevalence of major blood-borne infections in United States blood donors, 1995 to 2002: American Red Cross blood donor study. Transfusion 44: 1640-1647.

Zou S, Tepper M, Giulivi A 2000. Current status of hepatitis C in Canada. Can J Public Health 91: S10-5-S10-6. 